ELORE (ISSN 1456-3010), vol. $13-2 / 2006$.

Julkaisija: Suomen Kansantietouden Tutkijain Seura ry.

[http://cc.joensuu.fi/ /oristi/2_06/lau2_06.pdf]

\title{
Ajankohtaista:
}

\section{SUOSTA SISULLA JA SYDÄMELLÄ}

\section{Lectio praecursoria 18.8.2006 Joensuun yliopistossa}

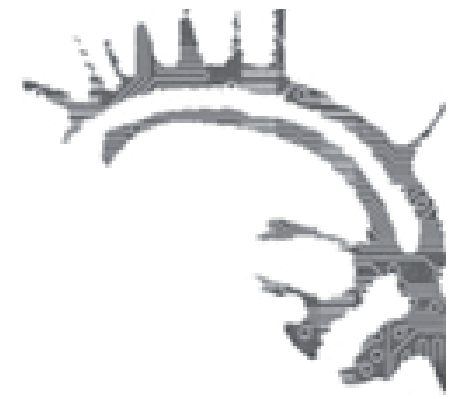

$\underline{\text { Kirsi Laurén }}$

Alussa oli pahvilaatikoittain suotarinoita, tuhansittain kirjoitettuja suokokemuksia. Siinä oli minun suoni, jonka haltuunottoon ja valloittamiseen eivät suontutkimuksessa ja käsittelyssä tutut, paljon käytetyt työkalut ja -menetelmät nyt riittäneet. Tästä suosta ei selvittäisikään kuokkimalla eikä räjäyttelemällä, se ei liioin antautuisi selitettäväksi kairaamalla, turvemaan kemiallisia ja fysikaalisia ominaisuuksia tarkastelemalla eikä kasvupaikka-analyyseilla. Vaikka näiden työvälineiden ja -menetelmien käytöstä suon selvittämisessä on, varsinkin meillä Suomessa, runsaasti kokemusta ja korkeatasoista tietämystä, niillä päädyttäisiin nyt korkeintaan ojasta allikkoon.

Edessäni oli kirjoitettuina teksteinä ilmaistu suo, jonka olemus rakentui merkitysvälitteisesti niistä kokemuksista, joita suomalaisilla on omakohtaisesti ollut suosta. Kyseessä oli siis kulttuurinen, inhimilliseen elämään limittyvä suo, josta oli saatavilla vain vähän aikaisempaa tutkimustietoa. Kokemuksellisen, kauno- ja dokumenttikirjallisuuden elementtejä sisältävän tutkimusaineiston haltuunotosta oli niin ikään olemassa vain niukalti tietoa. Oliko tässä nyt ylitsepääsemätön suo? Eihän toki, oli vain etsittävä ja luotava uusia, juuri tämän aineiston ja aiheen käsittelyyn sopivia työkaluja ja -menetelmiä, joiden avulla näkymättömissä pysytellyt tieto saataisiin näkyväksi. Käyttökelpoiset näkökulmat ja työvälineet löytyivät aineistolähtöisestä grounded theorysta ja kulttuurintutkimuksen, erityisesti tulkitsevan antropologian näkökulmista.

Kokemuksiin pohjautuvista teksteistä avautui suomalaisen suokulttuurin suorastaan hämmentävän rikas ja monipuolinen kirjo, johon oli kudottuna suonkäytön historia aina suopeltojen raivauksesta metsäojituksiin, turpeennostoon ja virkistykselliseen eräretkeilyyn ja elämysten tavoitteluun. Suokertomuksissa kuljettiin lukuisilla hilla- ja karpalosoilla, vajottiin suonsilmiin ja ihailtiin mahtavien kurkien tepastelua suolla. Toiminnallisten kuvausten ohella suokertomukset avasivat näkymiä myös suoluontosuhteen syvempiin kerroksiin. Aivan kuten suo säilöö arkiston tavoin arvokasta tietoa esimerkiksi menneisyyden ilmasto-olosuhteista, myös ihmisten mieliin oli kätkeytynyt muistiaarteita, hiljaista tietoa, joka nyt kirjoitettuina teksteinä tuli näkyville. Kun kirjoittajien äänille ja näkemyksille malttoi antaa tilaa, piirtyi teksteistä 
esiin suomalainen suonlaitaelämä iloineen ja murheineen, haaveineen ja huolineen. Kirjoittajat kertoivat, mitä suosta ja suolla on eri aikoina ja tilanteissa ajateltu, miten suohon on suhtauduttu ja miltä se on tuntunut. Tällaista kokemuksellista suota ei voinut mitata, laskea eikä määritellä yksiselitteisesti, kuten konkreettista, käsin kosketeltavaa suota, sillä se kietoutui ihmisten yksilölliseen ajatteluun, asenteisiin ja arvoihin. Sen sijaan oli mahdollista ja kiinnostavaa valaista tätä kirjoittajien henkilökohtaista tunne- ja arvomaailmaa ja tarkastella millaisia kulttuurisesti tyypillisiä, suohon liittyviä jaettuja merkityksiä siihen sisältyi.

Suot ovat olennainen osa Suomen luontoa ja metsien ohella ne herättävät aika ajoin myös vilkasta julkista keskustelua. 1990-luvun puolivälin tienoilla suota ruodittiin erilaisissa seminaareissa niin tieteen, taiteen kuin elinkeinoelämän näkökulmista. Tuolloin oltiin muun muassa huolestuneita luonnontilaisten soiden kohtalosta ja soiden käytön ympäristövaikutuksista. Edelleen pohdittiin myös esimerkiksi turvetuotannossa olleiden soiden jälkikäyttöä ja soiden luonnontilan palauttamisen mahdollisuuksia. Uutena näkökulmana suossa kiinnostivat sen esteettiset mahdollisuudet, joita pohdittiin muun muassa kansainvälisessä Suon estetiikkea -konferenssissa täällä Pohjois-Karjalassa. Suo tuntui kiehtovan tuolloin myös mediaa, jossa suoteema esiintyi monissa yhteyksissä. Myös niille, joilla ei ollut mahdollisuutta osallistua suoseminaareihin ja julkisiin keskusteluihin, tarjosi vuonna 1998 järjestetty Suotarina-kirjoituskilpailu väylän sanoa suosta sanottavansa, jos sitä oli. Ja sanottavaa tuntui olevan, kuten kyseisen kilpailun satoa tarkastelevassa väitöstutkimuksessanikin käy ilmi.

2000-luvulla suot ovat säilyttäneet kiinnostavuutensa. Niiden kiehtovuus ja julkisuusvetovoima ovat jopa lisääntyneet, mikä näkyy niin taiteessa kuin urheilu- ja populaarikulttuurissa. Soilta ammennetaan materiaalia ja inspiraatiota taide-esityksiin ja -teoksiin, tupasvillakuidusta valmistettaviin vaatteisiin, puutarhojen kasvualustoihin, terveysvaikutteisiin turvehoitoihin ja kosmetiikkaan. Luontomatkailun harrastajat ja kilpa- ja kuntourheilijat suuntaavat sauvoineen tarpomaan suolle, missä hiki virtaa, rasva palaa ja luonto antaa haasteita ja henkistä energiaa. Elokuvantekijät ja musiikkivideoiden luojat pitävät yllä myyttistä ja pelottavaakin suokuvaa, jossa monenmoiset henget liikkuvat usvaisilla, öisillä soilla, ja tummissa vesissä velloo murhattuja ja tapettuja ruumiita.

Suot ovat edelleen myös ympäristö- ja energiapoliittisten keskustelujen polttopisteessä. Meillä Suomessa etenkin turpeen energiakäyttö herättää kiivaita mielipiteitä puolesta ja vastaan. Kannetaan huolta turpeenkäytön haitallisista ilmasto- ja vesistövaikutuksista, ja toisaalta taas nopeasti muuttuvassa maailmassa turpeen turvaaman kansallisen energiaomavaraisuuden ja huoltovarmuuden säilyttäminen koetaan tärkeänä. Vähäisenä ei pidetä myöskään soiden työllistävää vaikutusta, joka heijastuu etenkin muuttotappioisten syrjäseutujen elinkeinorakenteeseen. Suotutkijat niin meillä kuin eri puolilla maailmaa miettivät kuumeisesti, kuinka voisimme ja osaisimme käyttää suoluontoa viisaasti ja kestävällä tavalla.

Tänä kesänä suot ovat olleet mediassa näkyvästi esillä. Tästä esimerkkinä on muun muassa Ylen TV 1:n Suo-keskusteluohjelma, jossa pohditaan lähtökohtaisesti, olivatko asiat ennen paljon paremmin. Suo esiintyy etupäässä keskustelijoiden ja erilaisten keskusteluteemojen visuaalisena taustana, mutta sen tarkoitus on mitä 


\section{KIRSI LAURÉN}

ilmeisimmin toimia eräänlaisena menneisyyteen viittaavana metaforana. Pysähtyneisyyttä, aitoutta ja erämaisuutta korostavan suon tehtävän ohjelmassa voi tulkita suhteellistavan ajankulun ja kyseenalaistavan nykyelämän kiihkeätahtisuuden. Kesän aikana lehdet ja televisio ovat välittäneet myös soiden ääreltä kantautuvaa itkua ja hammasten kiristystä: soillemme hillatulojen perässä tulleet itäeurooppalaiset ovat vuodattaneet pettymystään, kun suot ja metsät eivät kuivana kesänä tarjonneetkaan odotetulla tavalla antimiaan. Heinäkuussa media löysi myös suopotkupallon MM-kisat Hyrynsalmella, suolentiksen ensimmäiset maailmanmestaruuskisat Haukivuorella ja kansainvälisen soidensuojeluseuran vierailun Suomen soilla.

Kuumia, voisi sanoa jopa tulisia tunteita ovat julkisuudessa herättäneet etenkin viimeksi mainitun kansainvälisen tutkijajoukon antamat negatiiviset lausunnot Suomen soiden tilanteesta. Soillamme pari viikkoa kierrellyt tutkijajoukko oli tiedotteiden mukaan järkyttynyt siitä, miten meillä on peruuttamattomasti tuhottu soita maataloudella, metsäojituksilla ja turpeennostolla. Vierailunsa päätteeksi he antoivat julkilausumansa, jossa muun muassa kehotettiin Suomea nopeasti luopumaan turpeesta energialähteenä. Moitteiden ohella tutkijat myös kiittelivät soidemme monimuotoisuutta ja totesivat Suomen olevan yksi maailman merkittävimmistä suomaista ja suomalaisen tutkimuksen lisänneen suotietämystä maailmanlaajuisesti. Jostain syystä moitteet saivat mediassa suuremman painoarvon kuin kiitokset. Moitteet osuivat suomalaisten sydämiin ja asiaa puitiin kiivaasti lehtien pääkirjoituksissa, kolumneissa ja yleisönosastoilla. Närkästyneissä kirjoituksissa hämmästeltiin, unohtuiko arvon suohutkijoilta, että kolmannes Suomesta on suota - siis pinta-alaansa nähden meillä on suota enemmän kuin missään muussa maassa. Vaikka etenkin soiden metsäojituksissa meillä tehtiin virheitä, niistä huolimatta meillä vielä riittää luonnontilaisia soita. Kyseltiin myös sen perään, kuinka monen Suomea moittineen tutkijan omassa kotimaassa on jäljellä yhtään suota; vaaditaanko meitä nyt tekemään Suomesta suoreservaatti? Saarijärven Paavoon ja Koskelan Jussiin palaten muistutettiin, että meillä on aina osattu elää omin avuin soiden ja metsien keskellä, minkä vuoksi elämää täällä on ylipäänsä voitu ylläpitää.

Mieleeni heräsi väkisinkin kysymys: minkä verran kansainväliselle, etupäässä luonnon ekologiaan ja biologiaan erikoistuneelle tutkijajoukolle taustoitettiin suonkäyttöön liittyvää historiaamme ja suohon liittyvää kulttuurista kontekstia ylipäänsä? Tarkastin kansainvälisen soidensuojeluseuran sivuilla olevan Suomen soille suuntautuneen retkiohjelman. Siinä annettiin retkeläisille taustatietoja suomalaisesta luonnosta, eksakteja lukuja ja määrityksiä soistamme ja niiden sijainnista, suotyypeistämme, soiden hyötykäytöstä, suojelutilanteesta ja soita uhkaavasta ihmisen toiminnasta. Siitä, millaisissa tilanteissa ja miksi erilaisiin käyttömuotoihin on meillä eri aikoina päädytty, millaista elämää Suomessa on eletty ja millainen merkitys soilla on meille ollut ja on, ei mainita sanallakaan. Ihmisiä, muutoin kuin luonnon muuttajina ja tuhoajina, ei ainakaan internetin kautta välitetyssä informoinnissa huomioida. Tämä on varsin merkillistä, kun ottaa huomioon, että esimerkiksi suopellot Jusseineen ovat suomalaisessa kulttuurissa symbolisesti niin merkittäviä, että niiden katsotaan kuvastavan suomalaista kansanluonnetta ja kätkevän sisäänsä kulttuuriset juuremme. Tämä symboliarvo on 
edelleen sitkeästi voimissaan ja ilmeni paitsi omassa tutkimuksessani myös kirkkaasti soidensuojeluryhmän lausuntoja ruotivassa närkästyneessä lehtikirjoittelussamme.

Me ihmiset kuulumme osana luontoon - myös suoluontoon. On aivan oikein, että soita ja muutakin luontoa arvioidaan ja suojellaan ihmisen vastuuttomalta toiminnalta. Mutta olisi myös oikeutettua, että niin luonnontilaisia kuin tuotannollisiakin maisemia tarkasteltaessa olisi mahdollista saada tietää, mitä on maiseman takana; millainen kulttuurinen, yhteiskunnallinen ja historiallinen tilanne on johtanut kulloiseenkin luonnonkäyttöön. Yksisilmäisiltä vaikuttavien päätelmien, lausuntojen ja arvioiden antamisen vaaroilta vältyttäisiin paremmin, jos asioiden laaja-alaisemmalle ymmärtämiselle annettaisiin enemmän mahdollisuuksia. Luonnon ja sen ilmiöiden selittäminen on luonnontieteilijöiden työsarkaa. Sen sijaan luontosuhde, se miten ihminen elää luontoa, kuuluu ihmistieteilijöiden erityisalaan. Kuten edellä kertomani esimerkki mielestäni sangen selkeästi osoittaa, luonnontieteilijöiden ja ihmistieteilijöiden välinen vilkkaampi tiedonsiirto ja yhteistyö eivät olisi pahitteeksi.

Suomalaisen suokulttuurin ja luontosuhteen ymmärtäminen ja ymmärrettäväksi tekeminen moneen suuntaan rönsyilevästä ja laajasta suotarina-aineistosta on ollut oman tutkimusprosessini keskeisimpiä tavoitteita. Suokokemuksista kertovat tekstit ovat olleet tärkein ja pääasiallisin tutkimuskenttäni, jonne olen tehnyt lukuisia matkoja. Samalla olen halunnut opetella katsomaan suokulttuuriin liittyviä ilmiöitä mahdollisimman laaja-alaisesti ja tarkastella suota myös varsinaisen tutkimusaineistoni ulkopuolella. Suoaihe ja kertomukset ovat olleet mitä kiehtovin työsarka, vaikka helpolla eivät suotarinat ole päästäneet. Haastetta on riittänyt kuin hetteisessä suossa konsanaan. Onkin aika siirtyä tarkastelemaan, kuinka olen kyennyt haasteeseeni vastaamaan.

Kirsi Laurén: Suo - sisulla ja sydämellä. Suomalaisten suokokemukset ja -kertomukset kulttuurisen luontosubteen ilmentäjinä. SKST 1093. Helsinki: SKS. 2006.

Kirsi Laurén toimii tutkijana Suomen kielen ja kulttuuritieteiden oppiaineryhmässä Joensuun yliopistossa. 